\title{
A new predictor to determine the exacerbation and treatment of chronic obstructive pulmonary disease: eosinophil/neutrophil ratio
}

\author{
Halil ibrahim YAKAR ${ }^{1}(I D)$ \\ Asiye $\operatorname{KANBAY}^{2}$ (ID)
}

Cite this article as: Yakar Hi, Kanbay A. A new predictor to determine the exacerbation and treatment of chronic obstructive pulmonary disease: eosinophil/neutrophil ratio. Tuberk Toraks 2020;68(3):260-267.

Yazışma Adresi (Address for Correspondence)

Dr. Halil ỉbrahim YAKAR

Gaziosmanpaşa Üniversitesi Tıp Fakültesi,

Göğüs Hastalıkları Anabilim Dalı,

TOKAT - TÜRKIYE

e-mail: halilibrahim.yakar@gop.edu.tr

CCopyright 2020 by Tuberculosis and Thorax.

Available on-line at www.tuberktoraks.org.com
${ }^{1}$ Department of Chest Diseases, Faculty of Medicine, Tokat Gaziosmanpasa University, Tokat, Turkey

${ }^{1}$ Gaziosmanpaşa Üniversitesi Tıp Fakültesi, Gögüs Hastalıkları Anabilim Dalı, Tokat, Türkiye

2 Department of Chest Diseases, Faculty of Medicine, Istanbul Medeniyet University, Istanbul, Turkey

2 istanbul Medeniyet Üniversitesi, Göğüs Hastalıkları Anabilim Dalı, istanbul, Türkiye
ABSTRACT

A new predictor to determine the exacerbation and treatment of chronic obstructive pulmonary disease: eosinophil/neutrophil ratio

Introduction: COPD is an inflammatory disease characterized by persistent respiratory symptoms and airflow limitation. Currently, it has been demonstrated in some studies that eosinophil and $T$ helper- 2 mediated inflammation play a role in the pathophysiology of COPD.

Materials and Methods: It was planned to evaluate eosinophilia, eosinophil/ neutrophil ratio (ENR), distribution of ENR according to GOLD groups, number of exacerbations in last year, relationship between ENR and the rate of ICS use in COPD patients, and the ENR cut-off value that predicts eosinophilic COPD. This study was planned prospectively in stable COPD patients between July 2017 and December 2017. All patients were divided into two groups as eosinophilic and non-eosinophilic group. Eosinophilia was considered to be $>2 \%$ of peripheric blood eosinophils.

Results: A total of 206 stable COPD patients (127 eosinophilic and 79 noneosinophilic) were included. Age, gender, BMI, smoking history, mMrc score were statistically similar while average pack-year of smoking was significantly higher in eosinophilic group. ENR was significantly higher in eosinophilic group as expected $(p<0.001)$. High positive correlation was found between ENR and eosinophilic COPD $(r=0.8, p<0.001)$. In Group $D$, the number of eosinophilic COPD patients is significantly higher than the non-eosinophilic group while the distribution of patients in group $A, B, C$ was similar. Although the PFT findings were similar in both groups, the use of ICS was significantly lower and the number of exacerbations was significantly higher in eosinophilic group. In the ROC analysis, the ENR cut-off value that predicts eosinophilic COPD was found to be 0.32 in all COPD patients (Sens: $93.7 \%$, Specif: $92.4 \%, A \cup C=0.97, p<0.001$ ) 
Conclusion: Based on these findings, it is considered that more priority should be given to the use of ICS in COPD patients with high ENR and it can be used as a marker for predicting COPD exacerbation as COPD exacerbations are higher in patients with ENR.

Key words: COPD; eosinophil/neutrophil ratio; inhaler corticosteroids

ÖZ

Kronik obstrüktif akciğer hastalığında alevlenmeyi ve tedavisini belirlemek için yeni bir belirteç: eozinofil/nötrofil oranı

Giriş: KOAH, kalıcı hava yolu kısıtlanması ve solunumsal semptomlar ile karakterize inflamatuar bir hastalıktır. Son zamanlarda eozinofil ve $T$ helper-2 aracılı inflamasyonun KOAH patofizyolojisinde önemli rol oynadı̆̆ı gösterilmiştir.

Materyal ve Metod: $B u$ çalışmada stabil dönem KOAH'lılarda, eozinofili, eozinofil/nötrofil oranı (ENR), ENR'nin GOLD gruplarına göre dă̆ılımı, son bir yıl içindeki alevlenme sayısı, ENR ve IKS kullanım oranı ilişkisi, eozinofilik KOAH alevlenmesini predikte eden ENR cut-off değerinin araştırılması planlandı. Bu çalışma, Temmuz 2017 ile Aralık 2017 arasında stabil KOAH hastalarında prospektif olarak planlandı. Tüm hastalar eozinofilik ve eozinofilik olmayan grup olmak üzere iki gruba ayrıldı. Eozinofili, periferik kan eozinofillerinin > \%2'si olarak kabul edildi.

Bulgular: Toplam 206 stabil KOAH hastası (127 eozinofilik ve 79 non-eozinofilik) çalışmaya dahil edildi. Gruplar arasında yaş, cinsiyet, VKi, sigara öyküsü, mMrc skoru istatistiksel olarak benzer iken, eozinofilik grupta ortalama sigara paket yılı daha yüksek bulundu. ENR, eozinofilik grupta beklendiği gibi anlamlı yüksek bulundu $(p<0.001)$. ENR ve eozinofilik KOAH arasında pozitif korelasyon bulundu ( $r=0.8, p<0.001)$. Eozinofilik KOAH hastalarının sayısı D grubunda, non-eozinofilik gruptan anlamlı daha yüksek iken; $A$, $B, C$ grubunda hastaların dağılımı benzer bulundu. Her iki grupta da SFT bulguları benzer olmasına rağmen, eozinofilik grupta ICS kullanımı anlamlı olarak daha düşük ve alevlenme sayısı anlamlı olarak daha yüksek bulundu. ROC analizinde eozinofilik KOAH'ı predikte eden ENR değeri 0.32 olarak bulundu (Sens: \%93.7, Specif: \%92.4, AUC=0.97, p<0.001).

Sonuç: ENR'si yüksek KOAH hastalarında IKS kullanımına daha fazla öncelik verilmesi gerektiği düşünülmektedir. Ayrıca ENR'si yüksek hastalarda KOAH alevlenmelerinin daha sık olması nedeniyle KOAH alevlenmesini öngörmek için ENR'nin bir belirteç olarak kullanılabileceği düşünülmektedir.

Anahtar kelimeler: $K O A H$; eozinofil/nötrofil oranı; inhaler kortikosteroid

\section{INTRODUCTION}

Chronic Obstructive Lung Disease (COPD) is an inflammatory disease characterized by persistent respiratory symptoms and air flow limitation. COPD is currently the fourth cause of mortality worldwide, but it is estimated to be the $3^{\text {rd }}$ leading cause of death by 2020 (1). It is known that neutrophils, macrophages and CD8 T lymphocytes play a dominant role in the pathophysiology of COPD. Currently, it has also been demonstrated in some studies that eosinophil and $\mathrm{T}$ helper 2-mediated inflammation play a role in the pathophysiology of COPD (2). The sputum eosinophilia in both stable COPD and COPD exacerbation also indicates the role of eosinophilia in the pathogenesis of COPD (3). The development of COPD due to asthma and bronchial hyper reactivity also suggests that eosinophilia also plays a role in the pathophysiology of COPD. Thus, the eosinophilic phenotype was defined in COPD and the effects of inhaled corticosteroid (ICS) on COPD were also investigated in previous studies (4-6). In this study, it was aimed to evaluate the percentage of eosinophil count, eosinophil /neutrophil ratio (ENR), distribution of ENR according to Global Initiative for Chronic Obstructive Lung Disease (GOLD) groups, number of annual hospital admissions, relationship between ENR and the rate of ICS use in COPD patients durings stable period.

\section{MATERIALS and METHODS}

The study was planned prospectively in stable COPD patients who were referred to Göztepe Training and Research Hospital Department of Chest Diseases between December 2017 and April 2018. Local ethics committee approval was obtained from the Clinical Research Ethics Committee of the Göztepe Training and Research Hospital (protocol no. 2017/0371, 05.12.2017) before the study. All COPD patients were divided into 2 groups as eosinophilic group and non-eosinophilic group. Patients over 40 years of age with > 10 pack-year history of smoking or biomass exposure or occupational exposure and who were diagnosed as having COPD by a pulmonologist based on GOLD 2017 criteria were enrolled. Patients with allergic disease, using immunosuppressive drugs, having with active infection and hematologic disease, having with structural disease such as bronchiectasis and CF, having with a history of COPD exacerbation in the last month and not wishing to participate in the study were excluded. 
Basic characteristics and laboratory parameters were recorded and compared between the COPD patients and the control group. Age, gender, smoking history (pack-year), comorbidities, asthma history, exacerbation within the last one year, mMrc (Modified Medical Research Council) score, body mass index (BMI), pulmonary function test, percentage of eosinophil and neutrophil count, CRP, ENR, the rates of bronchodilator drug use in COPD treatment, relationship with ENR and GOLD stages were compared between two groups. Eosinophilia was considered to be $>2 \%$ of the eosinophil percentage in the blood hemogram. Blood eosinophil and neutrophil levels were calculated by measuring in the routine hemogram with the Pentra 120 Retic Hematology Analyzer (ABX, France). Analyzes were performed using SPSS version 20.0 (SPSS, Inc. Chicago, Illinois). The Kolmogorov-Smirnov test was used to test the distribution model of the variables. Continuous data were expressed as mean \pm standard deviation (SD). Variance analysis (ANOVA) was used for the GOLD stage and ENR relationship in eosinophilic COPD patients. Categorical variables were expressed as a percentage and compared with the chi-square test. $\mathrm{P}$ value $<0.05$ was considered statistically significant.

\section{Statistical Analysis}

The Kolmogorov-Smirnov test was used to test the distribution model of the variables. Parametric data were presented as mean \pm standard deviation $(\mathrm{SD})$. Comparison of multiple mean values was performed using variance analysis (ANOVA). Categorical variables were summarized as the percentage and were compared using chi-square tests. Pearson's correlation coefficient was calculated to analyze the relationship between ENR and COPD. Receiver operating characteristic (ROC) analysis was used to determine the ENR cut-off value that predicts exacerbation in COPD patients. Statistical analyses were performed using SPSS version 20.0 (SPSS, Inc. Chicago, Illinois). A P value $<0.05$ was considered statistically significant.

\section{RESULTS}

A total of 206 stable COPD patients were enrolled in this study. A total of 127 patients were included in the eosinophilic group (115 males, mean age $63.1 \pm$ $10.1)$ and 79 patients were in the non-eosinophilic group (68 males, mean age $62.8 \pm 10.0$ ). Age, gender, Body Mass Index (BMI), smoking history, mMrc dyspnea score were statistically similar while the average pack-year of smoking was significantly higher in the eosinophilic group (Table 1). Comorbid diseases (Hypertension (HT), Diabetes Mellitus (DM), Iscemic Heart Disease (ICD), Chronic Heart Failure (CHF) were similar in both groups. Percentage of Neutrophil count and C-reactive protein (CRP) level were significantly lower in patients with eosinophilic COPD ( $<<0.001, p<0.001$, respectively) (Table 2).

Asthma history was more common rate in eosinophilic COPD patients but it didn't receive statistically significance $(p=0.24)$ (Table 1$)$. Pulmonary function test findings $\left(\mathrm{FEV}_{1}, \mathrm{FVC}, \mathrm{FEV}_{1} / \mathrm{FVC}\right)$ were similar in both groups (Table 2). Although the PFT findings were similar, the number of exacerbations in the last one year was significantly higher in the eosinophilic group $(p<0.001)$ (Table 1).

When the both groups were compared separately in terms of treatment options, the use of inhale corticosteroids (ICS)+long-acting beta adrenoceptor agonists (LABA) was lower in the eosinophilic group $(\mathrm{p}=$ 0.018). The rates of use of other bronchodilator drugs were statistically similar (Table 1).

When the COPD patients were evaluated according to the $A, B, C$ and D subgroups based on the GOLD 2017 guideline, there were eosinophilic COPD patients significantly higher than non-eosinophilic patients in group $D$, while the distribution of patients in group A, B, C was similar (Table 2).

Among COPD patients, ENR was significantly higher than non-eosinophilic group $(p<0.001)$. High positive correlation was found between ENR and eosinophilic COPD ( $r=0.8, p<0.001)$. However, no significant relationship was found between ENR and GOLD A, B, C, and D subgroups $(f=0.84, p=0.47)$ (Figure 1-2).

In the ROC analysis, the ENR cut-off value that predicts eosinophilic COPD was found to be 0.32 in all COPD patients (sensitivity of $93.7 \%$ and specificity of 92.4\%) (AUC=0.97, 95\% Cl: 0.96-0.99, p $<0.001)$ (Figure 3).

\section{DISCUSSION}

Sixty percent of the COPD patients were in eosinophilic group in this study. There was high positive correlation was found between ENR and eosinophilic COPD. In Group D, the number of patients with eosinophilic COPD is significantly higher than the non-eosinophilic group while the distribution of 
Table 1. Clinical and demographic characteristics of COPD patients

\begin{tabular}{|c|c|c|c|}
\hline & Eosinophilic group & Non-eosinophilic group & $\mathbf{p}$ \\
\hline Patients, n (\%) & $127(61.6)$ & $79(38.4)$ & \\
\hline Male, n (\%) & $114(90)$ & $68(86)$ & 0.32 \\
\hline Age (year), mean \pm SD & $61.3 \pm 10.1$ & $62.8 \pm 10.0$ & 0.86 \\
\hline $\mathrm{BMI}\left(\mathrm{kg} / \mathrm{m}^{2}\right)$, mean $\pm \mathrm{SD}$ & $27.6 \pm 5.4$ & $27.4 \pm 4.8$ & 0.86 \\
\hline \multicolumn{4}{|l|}{ Comorbidity, n \% } \\
\hline HT & $16(12.6)$ & $11(13.9)$ & 0.78 \\
\hline DM & $12(9.5)$ & $6(7.6)$ & 0.20 \\
\hline IHD & $20(15.8)$ & $6(7.6)$ & 0.12 \\
\hline $\mathrm{CHF}$ & $2(1.6)$ & $5(6.3)$ & 0.07 \\
\hline CVD & $2(1.6)$ & $2(2.5)$ & 0.62 \\
\hline Asthma history, n (\%) & $24(18.8)$ & $10(12.6)$ & 0.34 \\
\hline \multicolumn{4}{|l|}{ Smoking history, n (\%) } \\
\hline None & $56(44.1)$ & $41(51.9)$ & 0.27 \\
\hline Ex-smoker & $49(38.5)$ & $22(27.8)$ & 0.11 \\
\hline Active smoker & $22(17.3)$ & $16(20.3)$ & 0.59 \\
\hline Cigarette $(P Y)$, mean \pm SD & $31.2 \pm 13.5$ & $25.5 \pm 14.8$ & 0.043 \\
\hline Exacerbation in last year & $0.76 \pm 0.11$ & $0.50 \pm 0.10$ & $<0.001$ \\
\hline mMrc dyspnea score & $1.43 \pm 0.63$ & $1.33 \pm 0.65$ & 0.44 \\
\hline \multicolumn{4}{|l|}{ COPD medication, $\mathrm{n}(\%) *$} \\
\hline none & $46(36.2)$ & $23(29.1)$ & 0.29 \\
\hline $\mathrm{ICS}+\mathrm{LABA}$ & $52(40.9)$ & $45(56.9)$ & 0.018 \\
\hline LAMA & $30(23.6)$ & $22(27.8)$ & 0.49 \\
\hline LABA & 15 (11.8) & $11(13.9)$ & 0.65 \\
\hline SAMA & $22(17.3)$ & $21(26.5)$ & 0.08 \\
\hline SABA & $16(12.6)$ & $6(7.6)$ & 0.25 \\
\hline Theophylline & $4(3.1)$ & $5(6.3)$ & 0.15 \\
\hline
\end{tabular}

patients in group A, B, C was similar (Table 2). Although the PFT data were similar in both groups, the use of ICS was significantly lower and the number of exacerbations was significantly higher in eosinophilic group.

Because of eosinophilia was also associated with the pathophysiology of asthma, it was assessed whether there was a significant difference in asthma history between the groups. In a previous study conducted by Kolsum et al., asthma history was found to be $28.6 \%$ in the eosinophilic group and $23.4 \%$ in the total COPD patients (7). According to this study, ineosinophilic group, asthma history was found to be higher than non-eosinophilic group, but it was not reached statistically significance. $(18.8 \%, 12.6 \%$ respectively, $\mathrm{p}=0.24)($ Table 1$)$.

A positive correlation have found between high $\mathrm{FEV}_{1}$ and eosinophilia in COPD patients in previous studies $(8,9)$. In fact, improvement in respiratory function through bronchodilator therapy has been better in COPD patients with eosinophilia (9). In this study, pulmonary function test findings ( $\mathrm{FEV}_{1}, \mathrm{FVC}_{1} \mathrm{FEV}_{1}$ / FVC) were similar between two groups (Table 2).

It has been shown in previous studies that patients with higher BMI are more likely to have allergic asthma and other eosinophilic patients $(10,11)$. It is thought to be related to the between obesity and visceral fat tissue and eosinophilia (12). However, BMI was similar in both groups in this study.It could be related the similarity of life and nutritional style of patients and the similarity of COPD stages.

Previous studies have shown that the risk of exacerbation is higher in COPD patients with an eosinophil count of $\geq 2 \%(13,14)$. In this study, patients with 
Table 2. Pulmonary Function Test Findings, Laboratory Findings and GOLD classification

\begin{tabular}{|c|c|c|c|}
\hline & $\begin{array}{c}\text { Eosinophilic group } \\
\text { mean } \pm \mathrm{SD}\end{array}$ & $\begin{array}{c}\text { Non-eosinophilic group } \\
\text { mean } \pm \text { SD }\end{array}$ & $\mathbf{p}$ \\
\hline $\mathrm{FEV}_{1} / \mathrm{FVC}(\%)$ & $53.4 \pm 11.1$ & $54.3 \pm 11.0$ & 0.06 \\
\hline $\mathrm{FEV}_{1}(\mathrm{~L} / \mathrm{min})$ & $2.03 \pm 0.77$ & $1.92 \pm 0.80$ & 0.22 \\
\hline $\mathrm{FEV}_{1}(\%)$ & $70.1 \pm 24.0$ & $67.8 \pm 23.1$ & 0.07 \\
\hline $\mathrm{FVC}(\mathrm{L} / \mathrm{min})$ & $2.93 \pm 3.81$ & $2.52 \pm 0.93$ & 0.37 \\
\hline FVC (\%) & $71.5 \pm 20.4$ & $70.8 \pm 20.3$ & 0.81 \\
\hline Leukocyte $\left(\mathrm{mm}^{3}\right)$ & $7906 \pm 1883$ & $8015 \pm 2600$ & 0.80 \\
\hline Hemoglobin $(\mathrm{g} / \mathrm{dL})$ & $13.80 \pm 1.48$ & $13.31 \pm 1.45$ & 0.09 \\
\hline Eosinophil count $(\mathrm{cell} / \mu \mathrm{L})$ & $299 \pm 190$ & $91 \pm 60$ & $<0.001$ \\
\hline Eosinophil \% & $3.74 \pm 2.12$ & $1.04 \pm 0.61$ & $<0.001$ \\
\hline Neutrophil count $\left(\right.$ cell $\left./ \mathrm{mm}^{3}\right)$ & $4570 \pm 1550$ & $5200 \pm 1875$ & 0.01 \\
\hline Neutrophil \% & $56.6 \pm 8.2$ & $64.1 \pm 9.5$ & $<0.001$ \\
\hline ENR & $0.07 \pm 0.04$ & $0.02 \pm 0.01$ & $<0.001$ \\
\hline $\mathrm{CRP}(\mathrm{mg} / \mathrm{L})$ & $0.90 \pm 0.21$ & $1.76 \pm 0.42$ & 0.05 \\
\hline \multicolumn{4}{|l|}{ GOLD classification, $\mathrm{n}(\%)$} \\
\hline A & $62(48.8)$ & $47(59.5)$ & 0.13 \\
\hline $\mathrm{B}$ & $37(29.1)$ & $26(33.3)$ & 0.56 \\
\hline $\mathrm{C}$ & $8(6.3)$ & $2(2.4)$ & 0.22 \\
\hline $\mathrm{D}$ & $19(14.9)$ & $4(4.8)$ & 0.028 \\
\hline
\end{tabular}

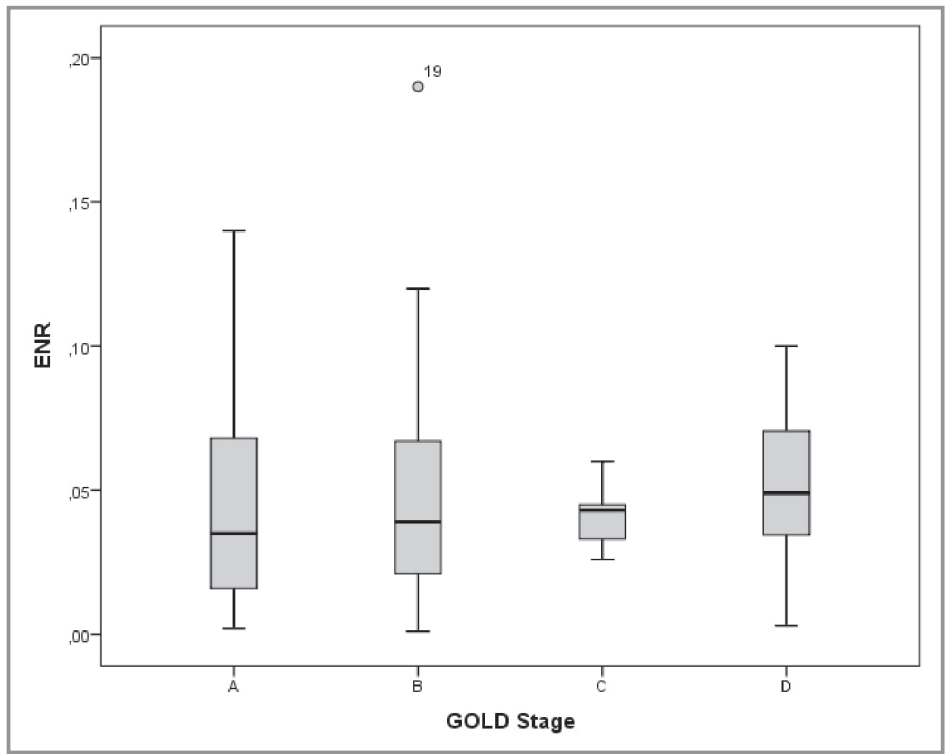

Figure 1. Association between group ENR and GOLD stages.

GOLD A $(n=109), \operatorname{GOLD~B~}(n=63)$, GOLD C $(n=10), \operatorname{GOLD} D(n=23)$. Data analyzed with one-way analysis of variance with Turkey post hoc test $(F=0.25$, $\mathrm{p}=0.86$ ). Error bars represent $95 \%$ Cls.

GOLD: Global initiative for chronic obstructive lung disease, ENR: Eosinophil neutrophil ratio. 


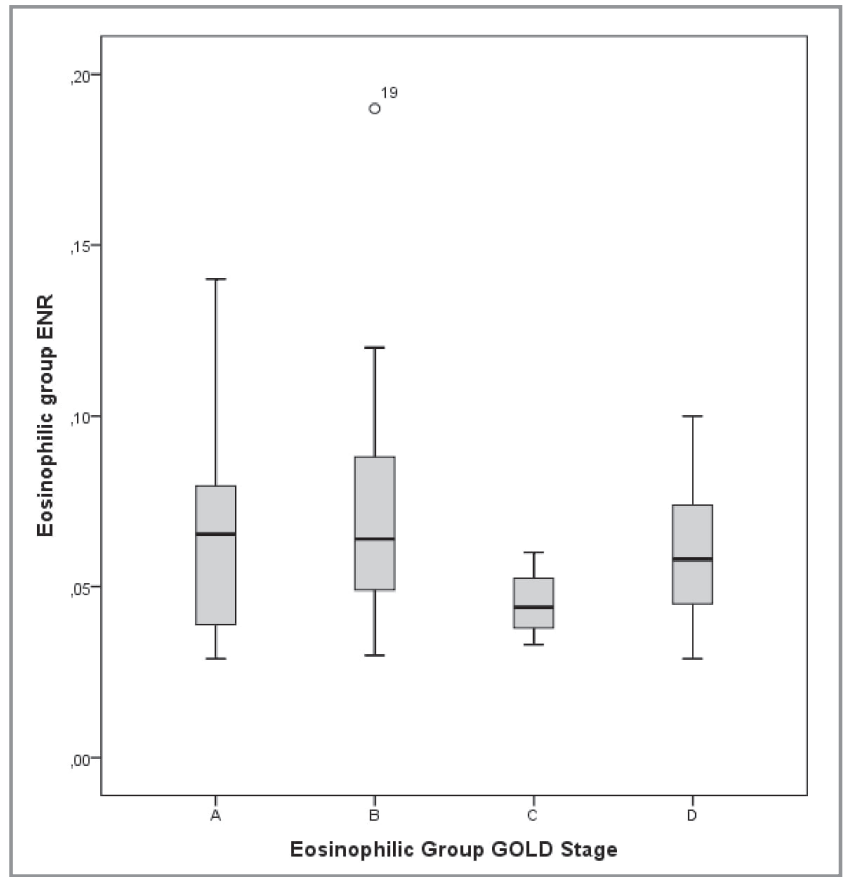

Figure 2. Association between group ENR and GOLD stages.

GOLD stage $1(n=62)$, GOLD stage $2(n=37)$, GOLD stage $3(n=8)$, GOLD stage $4(n=19)$. Data analyzed with one way analysis of variance with Tukey post hoc rest $(\mathrm{F}=0.84, \mathrm{p}=0.47)$. Error bars represent $95 \% \mathrm{Cls}$. GOLD: Global initiative for chronic obstructive lung disease, ENR: Eosinophil neutrophil ratio.

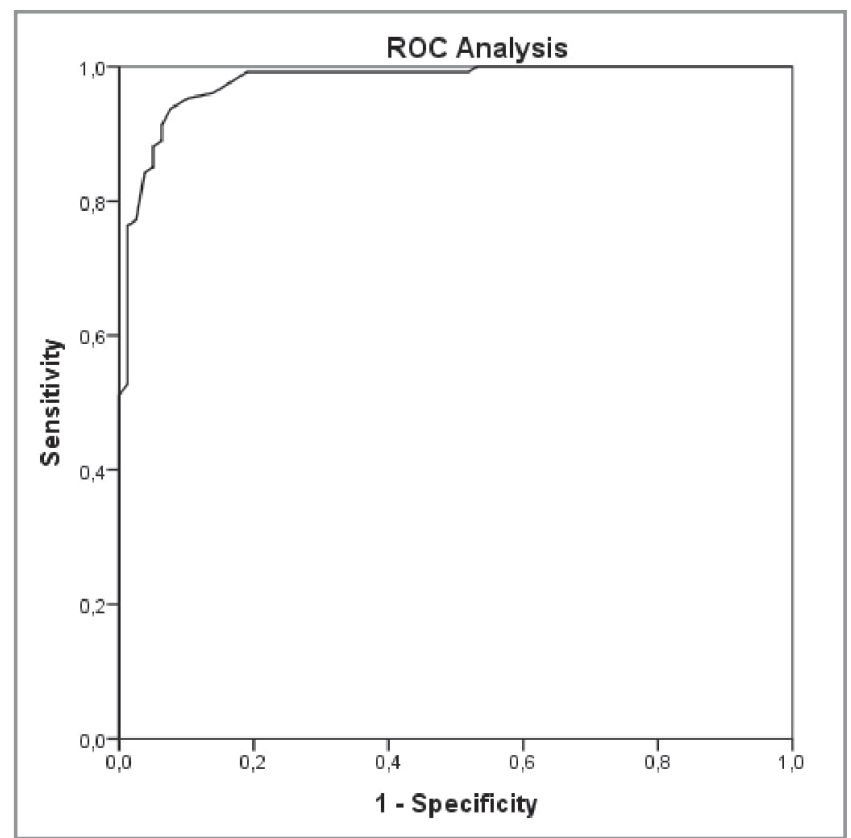

Figure 3. In the ROC analysis, the ENR cut-off value that predicts eosinophilic COPD was found to be 0.32 in all COPD patients (sensitivity of $93.7 \%$ and specificity of $92.4 \%$ ) (AUC $=0.97,95 \% \mathrm{Cl}: 0.96-0.99, \mathrm{p}<0.001)$.

GOLD: Global initiative for chronic obstructive lung disease, COPD: Chronic obstructive lung disease, ENR: Eosinophil neutrophil ratio. 
eosinophilic group also had a higher rate of exacerbation $(p<0.001)$ (Table 1). However, the rate of ICS use in this group was lower $(p<0.001)$. Whereas, ICS has been shown to reduce exacerbations and decrease annual decline of $\mathrm{FEV}_{1}$ in eosinophilic COPD in ISOLDE study (15). TORCH study also showed that ICS similarly reduced the number of annual exacerbations and annual decline of $\mathrm{FEV}_{1}$ in COPD, but in this study patients were not stratified by the number of blood eosinophils (16). We believe that the exacerbation of the eosinophilic group more frequently in this study may be related to the lower rate of ICS use.

When evaluated according to the GOLD 2017 guideline, there was no statistically significant relationship in terms of ENR between GOLD groups $(\mathrm{f}=0.84, \mathrm{p}=$ 0.47) (Figure 1-2). The proportion of patients with eosinophilic COPD was similar between the groups $A, B$, and C in this study. But, the proportion of eosinophilic patients was significantly higher than non-eosinophilic group in group D (Table 2). In a previous study, the risk of recurrence after exacerbation was higher in COPD patients with eosinophilia similarly (17). In another study, Zeiger et al. have shown that elevated blood eosinophil levels are an independent risk factor for COPD exacerbation (18). Therefore, in our study, it can be considered that eosinophilic COPD patients have more frequent exacerbation in similar with the literature.

In section of asthma treatment of the GOLD 2017 update, the use of ICS is only recommended as an alternative treatment in the $\mathrm{C}$ and $\mathrm{D}$ categories. In a study conducted by Günen et. al, the medication preferences of physicians were evaluated and the rate of combination therapy containing ICS was found to be about $81.9 \%$ in COPD outpatients (19). In this study, the rate of ICS use was $40.9 \%$ and $56.9 \%$ in the eosinophilic and non-eosinophilic group, respectively $(p=0.025)$. In addition, the ENR cut-off value that predicts eosinophilic COPD was found to be 0.32 in all COPD patients (Sensitivity: 93.7\%, Specificity: $92.4 \%, A \cup C=0.97)$. This shows that ICS therapy may be considered to be initiated, if ENR is upper than 0.32 in patients with COPD.

The fact that sputum eosinophilia has not been evaluated in COPD patients in the study can be considered as a limitation. Although examination of sputum eosinophilia is actually planned, eighty percent of the patients did not accept sputum examinations or could not give sputum. In addition, previous studies have shown that peripheral blood eosinophilia correlates well with airway eosinophilia (20). Therefore, it was based according to the results of blood eosinophilia. It is also known that eosinophilic inflammation in the respiratory tract is suppressed in patients using ICS (21) and some studies shown that sputum eosinophilia is not reliable in predicting the response to ICS treatment $(22,23)$. Thus, sputum eosinophilia was not evaluated. The other limitation is bronchodilator drug use techniques and treatment compliance of COPD patients were not taken into consideration in this study. However, training of BD tecniques were given by the same nurse to all patients in this study.

In conclusion; high positive correlation was found between ENR and eosinophilic COPD $(p<0.001)$. Although the PFT data were similar in both groups, the use of ICS was significantly lower and the number of exacerbations was significantly higher in eosinophilic COPD. Based on these findings, it is considered that more priority should be given to the use of ICS in COPD patients with high ENR. In addition, ENR can be used as a marker for predicting exacerbation and treatment of COPD as COPD exacerbations are higher in patients with high ENR.

\section{CONFLICT of INTEREST}

There is no conflict of interest related to this study.

Ethics Committee Approval: The approval for this study was obtained from Istanbul Medeniyet University Göztepe Training and Research Hospital Clinical Research Ethics Committee (Decision no: 2017/0371 Date: 05.12.2017).

\section{AUTHORSHIP CONTRIBUTIONS}

Concept/Design: HiY

Analysis/Interpretation: HIY, AK

Data Acquisition: HiY

Writting: HIY, AK

Critical Revision: HIY, AK

Final Approval: HIY, AK

\section{REFERENCES}

1. Global Initiative for Chronic Obstructive Lung Disease (GOLD). Global Strategy for the Diagnosis, Management and Prevention of Chronic Obstructive Pulmonary Disease 2017 Report, pp: 1-2.

2. Saha $S$, Brightling CE. Eosinophilic airway inflammation in COPD. Int I Chron Obstruct Pulmon Dis 2006; 1(1): $39-47$. 
3. Bathoorn E, Liesker IJ, Postma DS, Koëter GH, van der Thoorn $M$, van der Heide $S$, et al. Change in inflammation in out-patient COPD patients from stable phase to a subsequent exacerbation. Int I Chron Obstruct Pulmon Dis 2009; 4: 101-9.

4. Balbi B, Majori M, Bertacco S, Convertino G, Cuomo A, Donner CF, et al. Inhaled corticosteroids in stable COPD patients: do they have effects on cells and molecular mediators of airway inflammation? Chest 2000; 117: 1633-7.

5. Kunz LIZ, Ten Hacken NHT, Lapperre TS, Timens W, Kerstjens HAM, van Schadewijk A, et al. Airway inflammation in COPD after long-term withdrawal of inhaled corticosteroids. Eur Respir J 2017; 49(1): 1600839.

6. Soltani A, Walters EH, Reid DW Shukla SD, Nowrin K, Ward C, et al. Inhaled corticosteroid normalize some but not all airway vascular remodeling in COPD. Int I Chron Obstruct Pulmon Dis 2016; 11: 2359-67.

7. Kolsum U, Ravi A, Hitchen P, Maddi S, Southworth T, Singh $D$. Clinical characteristics of eosinophilic COPD versus COPD patients with a history of asthma. Respir Res 2017; 18(1): 73 .

8. Chou KT, Su KC, Hsiao YH, Huang SF, Ko HK, Tseng CM, et al. Post-bronchodilator reversibility of FEV1 and eosinophilic airway inflammation in COPD. Arch Bronconeumol 2017; 53(10): 547-53.

9. Park HY, Lee H, Koh WJ, Kim S, Jeong I, Koo HK, et al. Association of blood eosinophils and plasma periostin with FEV1 response after 3-month inhaled corticosteroid and long-acting beta2-agonist treatment in stable COPD patients. Int J Chron Obstruct Pulmon Dis 2015; 11: 23-30.

10. Kanazawa H, Yoshida N, Yamamoto H, Hara M, Hasegawa M, Matsuzawa S, et al. Risk factors associated with severity of eosinophilic otitis media. Auris Nasus Larynx 2014; 41(6): 513-7.

11. Bedolla-Barajas M, Morales-Romero J, Ramses-BedollaPulido T, Fabiola-Garcia-Padilla L, Hernandez-Colin D. Associated markers for adult-onset allergic asthma. Iran J Allergy Asthma Immunol 2015; 14(5): 545-51.

12. Clare M Lloyd, Sejal Saglani. Eosinophils in the spotlight: finding the link between obesity and asthma. Nat Med 2013; 19(8): 976-7.
13. Pascoe S, Locantore N, Dransfield MT, Pavord ID. Blood eosinophil count as a biomarker of ICS effectiveness in reducing exacerbation rates in COPD. Eur Respir J 2014; 44(Supp/ 58): 2817.

14. Pascoe S, Locantore N, Dransfield MT, Barnes NC, Pavord ID. Blood eosinophil counts, exacerbations and response to the addition of inhaled fluticasone furoate to vilanterol in patients with chronic obstructive pulmonary disease: a secondary analysis of data from two parallel randomised controlled trials. Lancet Respir Med 2015; 3(6): 435-42.

15. Burge PS, Calverley PMA, Jones PW, Spencer S, Anderson JA, Maslen TK. Randomised, double blind, placebo controlled study of fluticasone propionate in patients with moderate to severe chronic obstructive pulmonary disease: the ISOLDE trial. BMI 2000; 320(7245): 1297-303.

16. Celli BR, Thomas NE, Anderson JA, Ferguson GT, Jenkins $C R$, Jones $P W$, et al. Effect of pharmacotherapy on rate of decline of lung function in chronic obstructive pulmonary disease: results from the TORCH study. Am J Respir Crit Care Med 2008; 178(4): 332-8.

17. Prins HJ, Duijkers $R$, Lutter $R$, Daniels JM, van der Valk $P_{1}$ Schoorl M, et al. Blood eosinophilia as a marker of early and late treatment failure in severe acute exacerbations of COPD. Respir Med 2017; 131: 118-24.

18. Zeiger RS, Tran TN, Butler RK, Schatz M, Li Q, Khatry DB, et al. Relationship of blood eosinophil count to exacerbations in chronic obstructive pulmonary disease. J Allergy Clin Immunol Pract 2018; 6(3): 944-54.

19. Gunen H, Yilmaz M, Aktas O, Ergun P, Ortakoylu MG, Demir A, et al. Categorization of COPD patients in Turkey via GOLD 2013 strategy document: ALPHABET study. Int J Chron Obstruct Pulmon Dis 2015; 10: 2485-94.

20. Negewo NA, McDonald VM, Baines KJ, Wark PA, Simpson $J L$, Jones $P L$, et al. Peripheral blood eosinophils: a surrogate marker for airway eosinophilia in stable COPD. Int I Chron Obstruct Pulmon Dis 2016; 11: 1495-504.

21. Barnes PJ. A new approach to treatment of asthma. N Engl J Med 1989; 321(22): 1517-27.

22. Katz LE, Gleich GJ, Hartley BF, Yancey SW, Ortega HG. Ann Am Thorac Soc 2014; 11(4): 531-6.

23. Mukherjee M., Nair P. Blood or sputum eosinophils to guide asthma therapy? Lancet Respir Med 2015; 3(11): 824-5. 